\title{
MICROSTRUCTURE AND FATIGUE-CRACK GROWTH OF QUENCHED AND TEMPERED 23CrNiMoV STEEL
}

\author{
MIKROSTRUKTURA IN RAST UTRUJENOSTNE RAZPOKE V \\ POBOLJŠANEM 23CrNiMoV JEKLU
}

\author{
Shuaishuai Zhu ${ }^{1,2}$, Baosen Zhang ${ }^{1,2}$, Xiangyang Mao, ${ }^{1,2}$, Zhixin Ba ${ }^{1,2}$, \\ Yuming Dai ${ }^{1,2 *}$, Zhangzhong Wang ${ }^{1,2}$ \\ ${ }^{1}$ School of Materials Science and Engineering, Nanjing Institute of Technology, Nanjing 21167, China \\ 2Jiangsu Key Laboratory of Advanced Structural Materials and Application Technology, Nanjing 211167, China \\ Prejem rokopisa - received: 2019-09-05; sprejem za objavo - accepted for publication: 2019-12-23
}

doi:10.17222/mit.2019.210

The microstructure, mechanical properties and fatigue-crack growth of the heavy-forging steel $23 \mathrm{CrNiMoV}$ with quenching and tempering were systematically studied. Microstructural characterization involved an optical microscope, field-emission scanning electron microscope and a transmission electron microscope. The fatigue-crack growth (FCG) behavior of the stee tempered at $600{ }^{\circ} \mathrm{C}$ was investigated at various stress ratios. The microstructure of the $23 \mathrm{CrNiMoV}$ tempered at $600{ }^{\circ} \mathrm{C}$ was composed of tempered martensite and considerable $\mathrm{M}_{7} \mathrm{C}_{3}$-type acicular carbides and $\mathrm{M}_{23} \mathrm{C}_{6}$-type spheroidal carbides, which contributed to the excellent strengthening/toughness match of the steel. The high ultimate tensile strength (UTS), yield strength (YS), elongation and impact energy of the steel tempered at $600{ }^{\circ} \mathrm{C}$ were $1155 \mathrm{MPa}, 1091 \mathrm{MPa}, 15.4 \%$ and $102.9 \mathrm{~J}$, respectively. The FCG threshold $\left(\Delta K_{\mathrm{th}}\right)$ of the steel decreased with the increasing $\mathrm{R}$. The fatigue fracture was composed of tearing ridges and secondary cracks. Besides, the secondary cracks were easily caused by the spheroidal precipitates during cyclic deformation surrounding the fatigue crack tip, which may enhance the FCG rate.

Keywords: $23 \mathrm{CrNiMoV}$ steel, microstructure, precipitates, fatigue-crack growth

Avtorji članka so sistematično študirali mikrostrukturo, mehanske lastnosti in rast utrujenostne razpoke s kovanjem močno deformiranega in poboljšanega (kaljenega in popuščenega) jekla 23CrNiMoV. Mikrostrukturno karakterizacijo jekla so izvedli z optičnim (LM), vrstičnim elektronskim mikroskopom na emisijo polja (FE/SEM) in z presevnim elektronskim mikroskopom (TEM). Rast utrujenostne razpoke (FCG; angl.: fatigue crack growth) so opazovali $\mathrm{v}$ jeklu, popuščenem pri $600{ }^{\circ} \mathrm{C}$, in pri različnih napetostnih razmerjih R. Mikrostruktura poboljšanega jekla $23 \mathrm{CrNiMoV}$ je bila sestavljena iz popuščenega martenzita, znatno količino igličastih karbidov tipa $M_{7} C_{3}$ in kroglastih karbidov tipa $M_{23} C_{6}$, ki prispevajo k odličnemu utrjevanju jekla in povečanju njegove žilavosti. Jeklo popuščeno pri $600{ }^{\circ} \mathrm{C}$ je imelo natezno trdnost (UTS) $1155 \mathrm{MPa}$, mejo tečenja (YS) $1091 \mathrm{MPa}$, raztezek $15,4 \%$ in udarno žilavost $102,9 \mathrm{~J}$. Mejna napetost rasti utrujenostne razpoke $\left(\Delta K_{\text {th }}\right)$ je pri preiskovanem jeklu padala z naraščajočim napetostnim razmerjem. Na prelomu jekla nastalega zaradi njegovega utrujanja so bile vidne brazde in sekundarne razpoke. Poleg tega so kroglični izločki pospeševali nastanek sekundarnih razpok med ciklično deformacijo v okolici konice razpoke, kar lahko še dodatno pospešuje hitrost rasti utrujenostne razpoke.

Ključne besede: $23 \mathrm{CrNiMoV}$ jeklo, mikrostruktura, izločki, rast utrujenostne razpoke

\section{INTRODUCTION}

The low- and medium-carbon CrNiMoV steels are widely used as heavy-forging materials, such as for the brake discs and axles on high-speed trains, low-pressure rotors and pressure vessels, ${ }^{1-4}$ because of the good formability, high hardenability, ultra-high strength and fatigue strength, high creep resistance and heat-shock resistance. Some of the reasons for this are that the alloyed elements $(\mathrm{Cr}, \mathrm{Ni}, \mathrm{Mo}, \mathrm{V})$ promote the precipitation of alloy carbides, which mainly precipitated on the austenite/ferrite interface or in supersaturated austenite and ferrite during the thermo-mechanical treatments and heat treatments..$^{5-7}$ Many studies have focused on the evolution of carbides during the process of hot forging or quenching and tempering. The precipitation behavior of the carbides can be controlled by thermo-mechanical

*Corresponding author's e-mail:

y.m.dai@hotmail.com (Yuming Dai) processes. ${ }^{8,9}$ The alloy carbides of the interphase precipitation are arranged periodically with a low density of dislocations, and the average diameters of the carbides are a few nanometers to several tens of nanometers. ${ }^{10,11}$ The research of Ebrahimi et al. ${ }^{12}$ on $26 \mathrm{NiCrMoV}$ steel indicated that the dynamic precipitation of carbide particles could effectively postpone dynamic recrystallization, and the dynamic precipitation occurred at temperatures below $1000{ }^{\circ} \mathrm{C}$ and strain rates of $0.001-1 \mathrm{~s}^{-1}$. Wang et $\mathrm{al}^{13}$ reported that hot-deformation promotes the diffusion of the $\mathrm{C}$ in micro-alloyed steels and the formation of coarse ( $\mathrm{Ti}, \mathrm{Mo}) \mathrm{C}$ precipitates.

On the other hand, the nano-carbides should be precipitated during the high-temperature tempering of martensite or bainite. Those carbides are finely dispersed in the martensitic lath or bainitic ferrites with a high density of dislocations. ${ }^{14-16}$ Moreover, many researches show that the dispersed nano-carbides in alloyed steels bring high strength and excellent plasticity. Li et al. ${ }^{17}$ studied the effect of microstructure evolution on the 
Table 1: Chemical composition of 23CrNiMoV alloyed steel (mass fraction, $w / \%$ )

\begin{tabular}{|c|c|c|c|c|c|c|c|c|c|}
\hline $\mathrm{C}$ & $\mathrm{Si}$ & $\mathrm{Mn}$ & $\mathrm{Cr}$ & $\mathrm{Ni}$ & $\mathrm{Mo}$ & $\mathrm{V}$ & $\mathrm{Cu}$ & $\mathrm{Al}$ & $\mathrm{Fe}$ \\
\hline
\end{tabular}

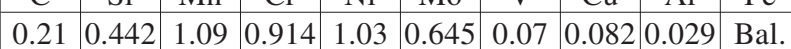

strength and impact toughness of G18CrMo2-6 steel. The study found that the precipitation and refinement of $\mathrm{MC}, \mathrm{M}_{3} \mathrm{C}$ increase the strength and toughness, but the precipitation and coarsening of $\mathrm{M}_{23} \mathrm{C}_{6}$ at the ferrite grain boundaries decreases the impact toughness sharply. The yield ratio of heat-treated $\mathrm{Mn}-\mathrm{Ni}-\mathrm{V}$ steels became high (from 0.7 to 0.9 ) compared to unalloyed steel on account of the strengthening of vanadium precipitates during the quench and temper process. ${ }^{18}$ Meanwhile, many investigators have paid more attention to the fatigue behaviour of the precipitation strengthening alloy. Both the fatigue strength and fatigue strength ratio of the micro-alloyed steel increase with the fine precipitation of MC carbides. ${ }^{19}$ The appropriate controlling of the carbides precipitation is a promising way to enhance the fatigue performance. ${ }^{20}$ The fatigue-crack propagation rate is significantly influenced by the matrix precipitate characteristics due to a smaller cyclic plastic zone of the alloy. ${ }^{21,22}$

The aim of the present paper is to study the precipitation strengthening of the heavy-forging steel $23 \mathrm{NiCrMoV}$ with quenching and tempering. The microstructure and mechanical properties of the $23 \mathrm{NiCrMoV}$ steel with different tempering temperatures were evaluated. Meanwhile, the fatigue-crack propagations of the $23 \mathrm{NiCrMoV}$ steel with high strength and toughness were investigated.

\section{EXPERIMENTAL PART}

The material investigated was a $23 \mathrm{CrNiMoV}$ steel for high-speed trains' wheel-mounted brake discs forged at $1200{ }^{\circ} \mathrm{C}$. The chemical composition of the steel is listed in Table 1. The samples were cut out with a size of $100 \mathrm{~mm} \times 50 \mathrm{~mm} \times 30 \mathrm{~mm}$ from the hot-forged brake disc. The preparatory heat treatment process was normalised at $900{ }^{\circ} \mathrm{C}+$ isothermal annealed at $600{ }^{\circ} \mathrm{C}$, which was used to eliminate the coarse and mixed crystals structure produced by the forging process. The samples had a mixed microstructure of ferrite and pearlite with a grain size of approximately 25-35 $\mu \mathrm{m}$ after the preparatory heat treatment. The pre-treated samples were austenitized at $900{ }^{\circ} \mathrm{C}$ for $1 \mathrm{~h}$ followed by a cooling in iced water. Then, those samples were tempered at $550{ }^{\circ} \mathrm{C}, 600{ }^{\circ} \mathrm{C}$ and $650{ }^{\circ} \mathrm{C}$ for $2 \mathrm{~h}$. The heattreatment processes were carried out in a box resistance furnace. Heat-treated samples were mechanically polished using standard metallographic procedures and etched with $4 \%$ nital for examination of the microstructure. The microstructure of the specimen was observed by optical microscopy (OM) and scanning electron microscopy (SEM). The transmission electron

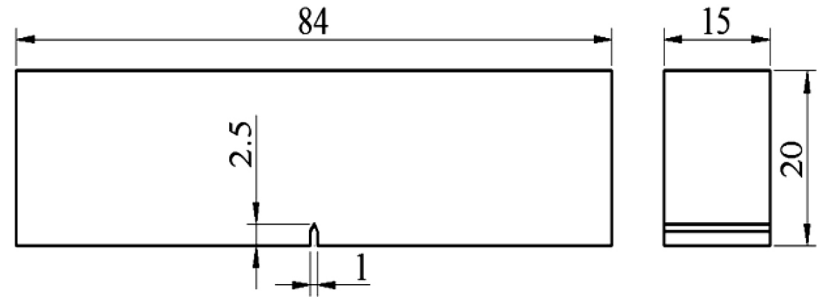

Figure 1: Schematic diagram of the SENB3 specimen dimensions $(\mathrm{mm})$

microscope (TEM) was used to analyse the morphology and structure of the precipitations.

Mechanical properties were determined through hardness, tensile and impact tests at room temperature. Tensile specimens were machined to a length of $90 \mathrm{~mm}$ and a diameter of $6 \mathrm{~mm}$ according to ASTM: E8 specification. The tensile tests were conducted at room temperature using a Sans CMT5105 materials testing system with a cross-head speed of $2 \mathrm{~mm} \mathrm{~min}^{-1}$. The Charpy V-notched impact tests were performed on a JBW-300H impact-test machine according to the ASTM E23 standard, using $(10 \times 10 \times 55) \mathrm{mm}$ specimens. The fatigue-crack growth (FCG) tests of the $23 \mathrm{NiCrMoV}$ steel were conducted in an Amsler HFP5100 fatigue test machine with the SENB3 specimens according to the ISO 12108 standard. Figure 1 shows the adopted dimensions for the SENB3 specimens. The load-shedding technique was used to obtain the $\Delta K_{\text {th }}$ value by decreasing the load steps at selected crack-size intervals using the following equation

$$
C=\left(\frac{1}{K}\right) \cdot\left(\frac{\mathrm{d} K}{\mathrm{~d} a}\right)
$$

where $C$ is the normalized $K$-gradient and $a$ is the crack length. During $K$-decreasing process, the $C$ value was controlled between $-0.05 \mathrm{~mm}^{-1}$ and $-0.15 \mathrm{~mm}^{-1}$. The fatigue-crack length was automatically measured using a CCD camera and an image-processing system.

\section{RESULTS AND DISCUSSION}

\subsection{Microstructures}

The microstructures corresponding to the different tempering temperatures of the $23 \mathrm{CrNiMoV}$ steels are shown in Figure 2. The microstructures of the tempered steels consist of tempered martensite. The tempered martensites have a significant influence on the strength and toughness of the CrNiMoV steels. Figure 2a indicates that the microstructure consists of nearly all martensitic lath after tempering at $550{ }^{\circ} \mathrm{C}$. Figure $\mathbf{2 b}$ and Figure 2c show that the size of the tempered martensitic lath decreased with the tempering temperature for the decomposition of the carbides. The fine martensitic should promote the increase of the toughness ${ }^{23}$.

Figure 3 shows the SEM micrograph of the as-quenched $23 \mathrm{CrNiMoV}$ steels tempered at $550{ }^{\circ} \mathrm{C}$, $600{ }^{\circ} \mathrm{C}$ and $650{ }^{\circ} \mathrm{C}$ for $2 \mathrm{~h}$. The microstructures of the 

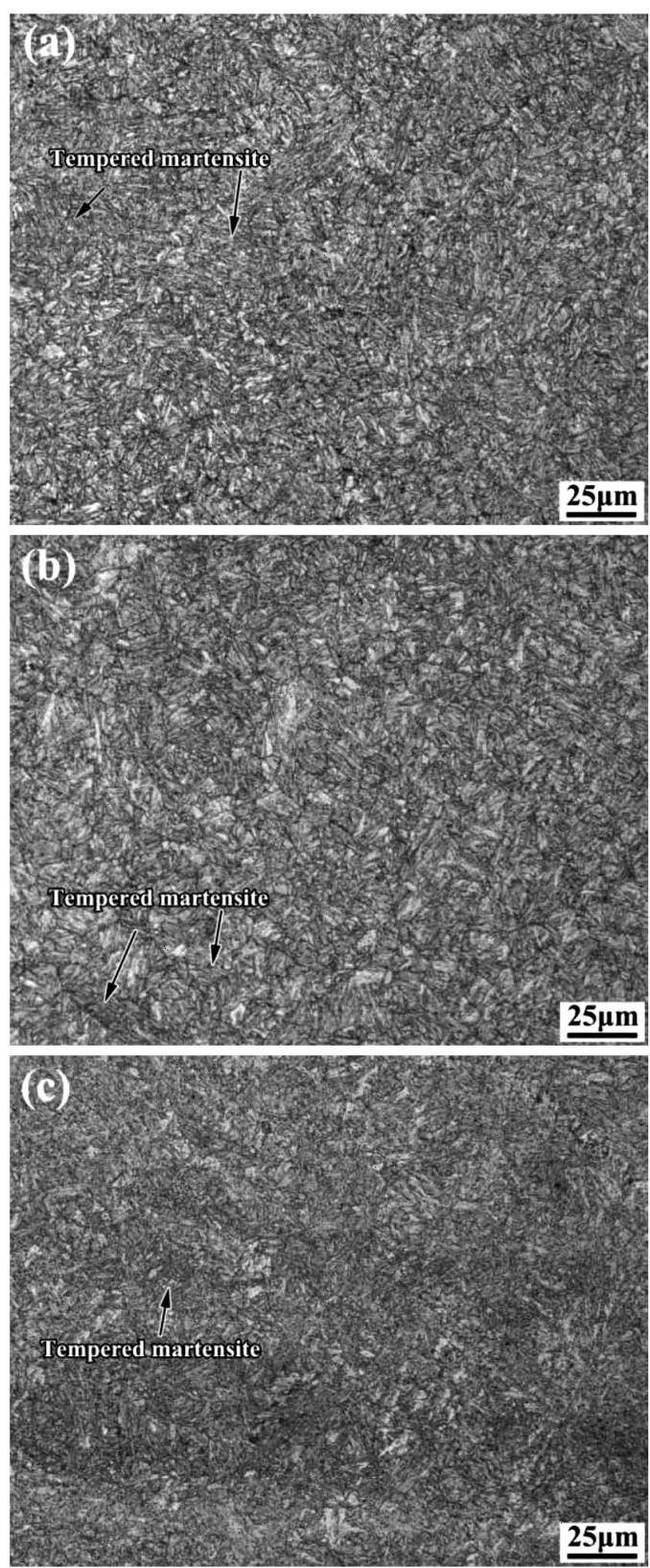

Figure 2: OM micrograph of the as-quenched $23 \mathrm{CrNiMoV}$ steels after tempered at: a) $550{ }^{\circ} \mathrm{C}$, b) $600{ }^{\circ} \mathrm{C}$, c) $650{ }^{\circ} \mathrm{C}$

tempered martensites consist of lath ferrites and precipitated carbides. The carbide precipitates have a plate-like structure at $550{ }^{\circ} \mathrm{C}$, and the precipitates are mainly acicular carbides and spheroidal carbides at $600{ }^{\circ} \mathrm{C}$ and $650{ }^{\circ} \mathrm{C}$. The evolution of the carbide morphology corresponds to the change of tempered martensite morphology shown in Figure 2. The acicular carbides precipitated mainly in the martensite lath, the spheroidal carbides precipitated mainly at the inter-plate boundaries and the prior austenite grain boundaries. According to the comparison among Figure 3a to $\mathbf{3 c}$, the acicular carbides mainly precipitated during the tempering of $600{ }^{\circ} \mathrm{C}$. The acicular carbides could transform into the spheroidal
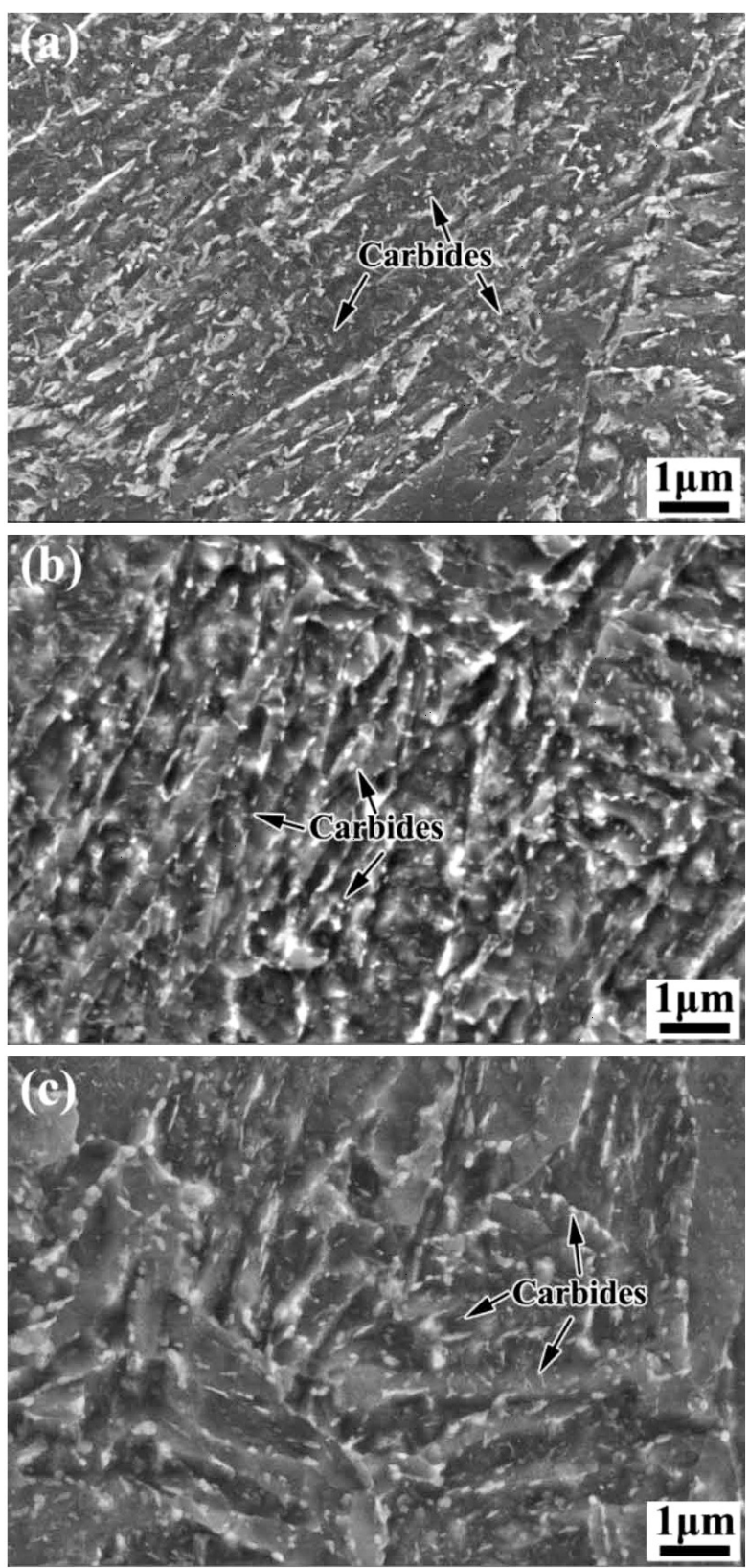

Figure 3: SEM micrograph of the as-quenched $23 \mathrm{CrNiMoV}$ steels tempered at: a) $550{ }^{\circ} \mathrm{C}$, b) $600{ }^{\circ} \mathrm{C}$, c) $650{ }^{\circ} \mathrm{C}$

carbides as the tempering temperature increased to $650{ }^{\circ} \mathrm{C}$, which was in line with the values reported previously for similar CrNiMoV alloyed steels..$^{24,25}$ The size and amounts of the precipitates increased with the increasing tempering temperature. The polygon ferrites were observed in Figure 3c, which indicated that more martensite laths were decomposed with tempering at $650{ }^{\circ} \mathrm{C}$. Figure 4 shows the TEM micrograph and the corresponding selected-area electron-diffraction (SAED) pattern of the steel tempered at $600{ }^{\circ} \mathrm{C}$. As shown in Figue 4, the acicular carbides dispersed and precipitated in the matrix with the size of $35 \mathrm{~nm} \times 200 \mathrm{~nm}$. Those acicular carbides enhanced the strength and toughness 


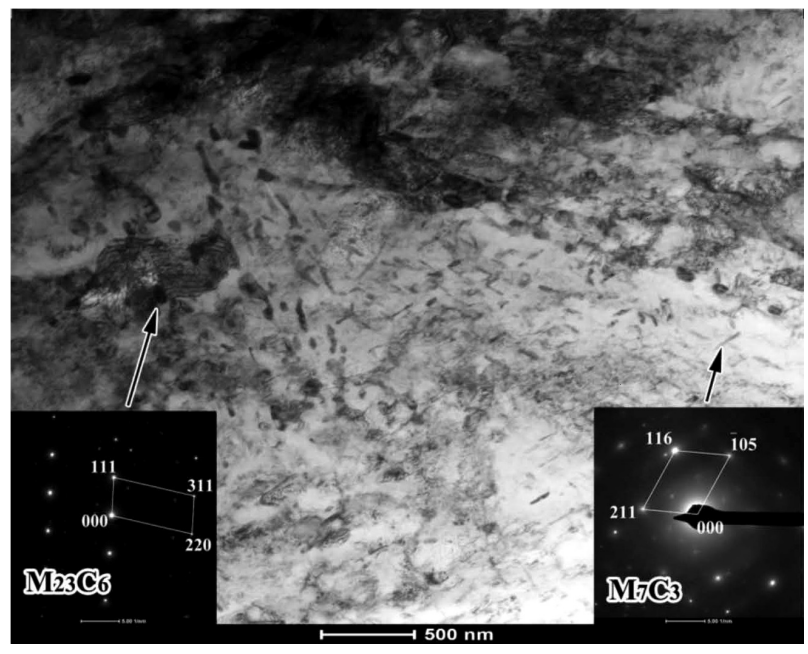

Figure 4: TEM micrograph of the as-quenched $23 \mathrm{CrNiMoV}$ steel after tempering at $600{ }^{\circ} \mathrm{C}$

due to the precipitation strengthening, the spheroidization and refinement of the carbides during the tempering process. The chains of the precipitation consist of spheroidal carbides precipitated at the phase and grain boundary with a size of about $150 \mathrm{~nm}$. Those precipitation chains reduced the interface bonding strength which were harmful to the ductility and toughness. The SAED patterns (the inserts in Figure 4) indicate that the acicular precipitates were $\mathrm{M}_{7} \mathrm{C}_{3}$-type carbides, and the spheroidal precipitates were $\mathrm{M}_{23} \mathrm{C}_{6}$-type carbides. ${ }^{18} \mathrm{In}$ addition, the dislocation density in the martensite lath region was high, which should have a beneficial effect on the strength.

\subsection{Mechanical Properties}

Figure 5 shows the typical engineering stress-strain curves of the specimens tested at room temperature. The curves indicate that the ultimate tensile strength (UTS), yield strength (YS) of the steel decreased with the increasing tempering temperatures. The measured mechanical properties including yield strength, tensile strength, total elongation, impact energy and hardness of steels are summarized in Table 2. The high UTS, YS and hardness of the steel tempered at $550{ }^{\circ} \mathrm{C}$ were $1251 \mathrm{MPa}$, $1176 \mathrm{MPa}$ and $376.7 \mathrm{HV}$, respectively. The UTS, YS and hardness of the steel tempering at $600{ }^{\circ} \mathrm{C}$ were only $7.6 \%, 7.2 \%$ and $7.0 \%$ lower than that of the steel tempered at $550{ }^{\circ} \mathrm{C}$. Furthermore, the elongation and impact energy of the steel tempered at $600{ }^{\circ} \mathrm{C}$ were $15.4 \%$ and $102.9 \mathrm{~J}$, which were $7.7 \%$ and $67.0 \%$ higher than that of the steel temperied at $550{ }^{\circ} \mathrm{C}$. Figure 6 is the Charpy impact test fracture surface of the steel tempered at $550{ }^{\circ} \mathrm{C}, 600{ }^{\circ} \mathrm{C}$ and $650{ }^{\circ} \mathrm{C}$. Figure 6a indicates that the steel tempered at $550{ }^{\circ} \mathrm{C}$ exhibits representative cleavage crack, and a very small plastic region has been found in this region. Figure $\mathbf{6 b}$ shows that the steel tempered at $600{ }^{\circ} \mathrm{C}$ displays the feature of the cleavage contained

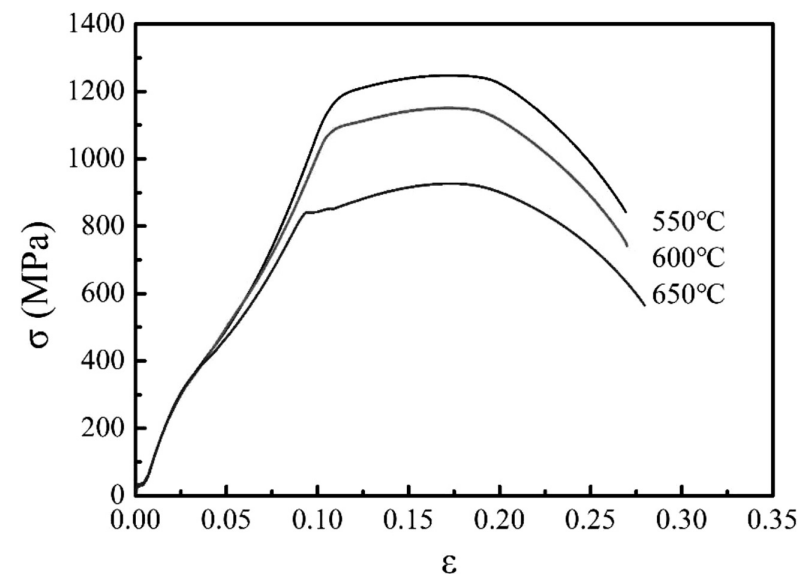

Figure 5: Experimental engineering stress-strain curves after different tempering temperatures
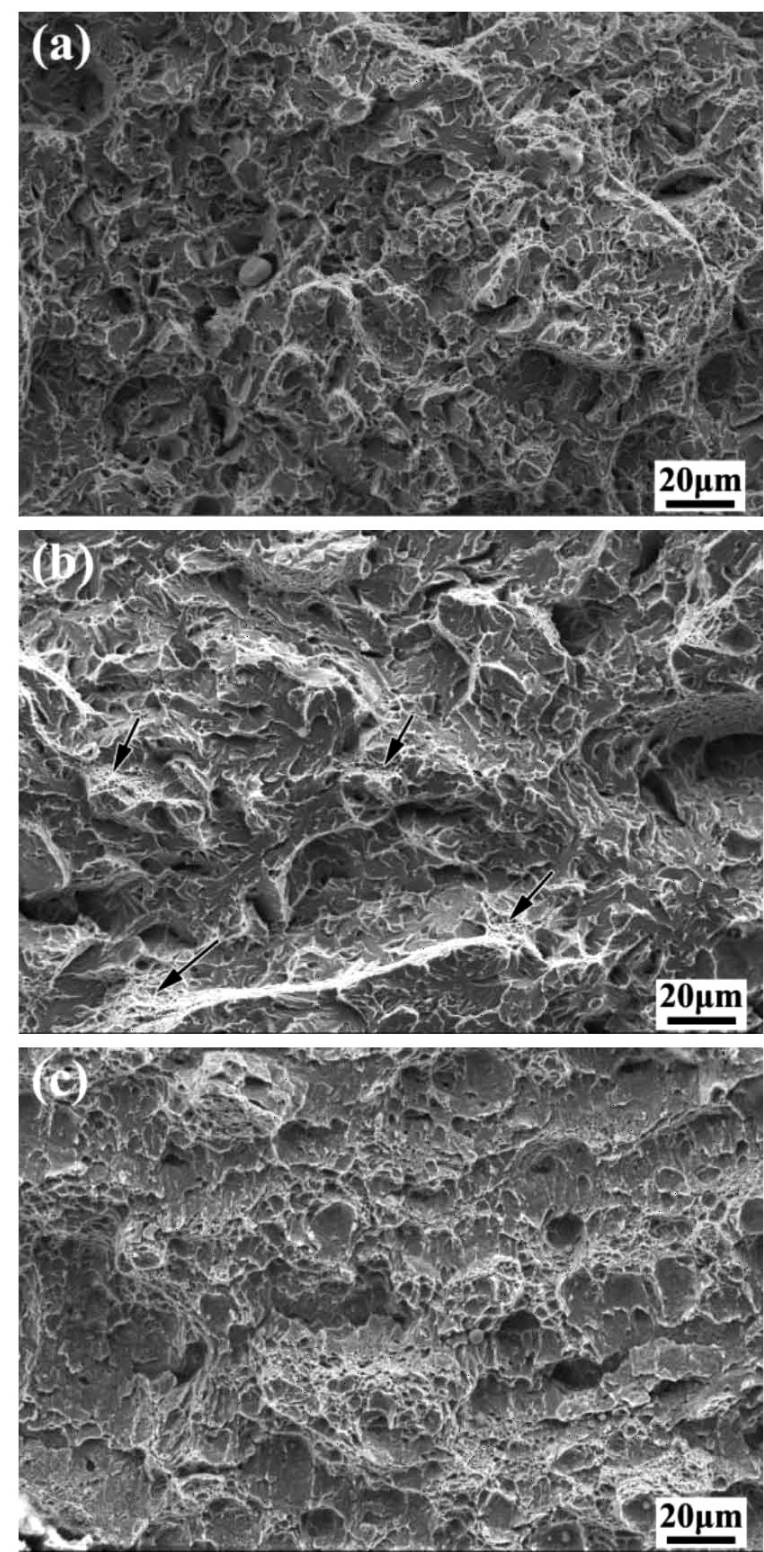

Figure 6: Charpy impact test fracture surface of the steel tempered at: a) $550{ }^{\circ} \mathrm{C}$, b) $600{ }^{\circ} \mathrm{C}$, c) $650{ }^{\circ} \mathrm{C}$ 
some toughness region and equiaxed dimples (shown with arrows). Figure $\mathbf{6 c}$ indicates that the fracture of the steel tempered at $650{ }^{\circ} \mathrm{C}$ has a significant plastic zone and a large number of equiaxed dimples. The high strength and toughness of the steel tempered at $600{ }^{\circ} \mathrm{C}$ were caused by the mixed microstructure of tempered martensites and the secondary hardening of the acicular $\mathrm{M}_{7} \mathrm{C}_{3}$-type carbides. ${ }^{26,27}$ For the recovery and decomposition of the martensies and the growth of the carbides tempering at $650{ }^{\circ} \mathrm{C}$, the tensile strength (UTS and YS) and hardness of the steel were relatively low, but, the ductility and toughness were high. ${ }^{28}$

Table 2: Determined mechanical properties at different tempering temperatures

\begin{tabular}{|l|c|c|c|}
\hline \multicolumn{1}{|c|}{ Tempering temperature } & $550{ }^{\circ} \mathrm{C}$ & $600{ }^{\circ} \mathrm{C}$ & $650{ }^{\circ} \mathrm{C}$ \\
\hline UTS / MPa & 1251 & 1155 & 924 \\
\hline YS / MPa & 1176 & 1091 & 844 \\
\hline Elongation / \% & 14.3 & 15.4 & 19.1 \\
\hline Impact energy / J & 61.6 & 102.9 & 172.8 \\
\hline Hardness / HV & 377 & 350 & 294 \\
\hline
\end{tabular}

\subsection{Fatigue-Crack Propagation Behavior}

Figure 7 shows the curves of the fatigue-crack growth (FCG) rate versus the applied stress-intensity factor range ( $\mathrm{d} a / \mathrm{d} N-\Delta K$ curves) of the as-quenched $23 \mathrm{CrNiMoV}$ steel tempered at $600{ }^{\circ} \mathrm{C}$ at stress ratio $R=$ $0.1,0.25$ and 0.5 . The fatigue crack growth threshold $\left(\Delta K_{\mathrm{th}}\right)$ decreased with the increase of $R$. The way to determine the threshold was using a straight line fitted to a minimum of five $\log (\mathrm{d} a / \mathrm{d} N)$ versus $\log (\Delta K)$ data pairs between $10^{-6} \mathrm{~mm} /$ cycle and $10^{-7} \mathrm{~mm} /$ cycle. The $\Delta K_{\text {th }}$ can be calculated by the Paris-Erdogan equation ${ }^{29}$ :

$$
\frac{\mathrm{d} a}{\mathrm{~d} N}=C_{1} \Delta K^{n_{1}}
$$

where $C_{1}$ and $n_{1}$ are the intercept and slope of the fitting line, respectively. The value of $\Delta K$ corresponding to a crack growth rate equal to $10^{-7} \mathrm{~mm} /$ cycle is defined as

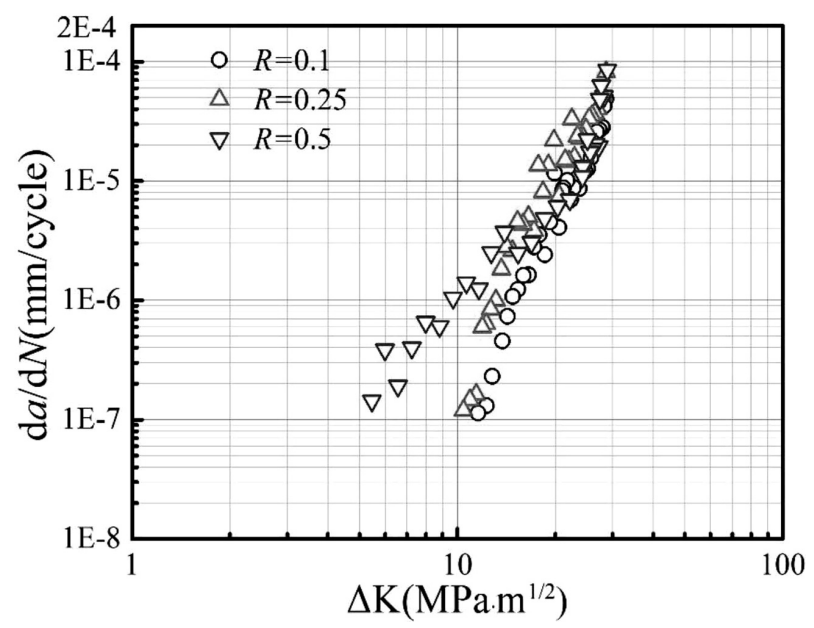

Figure 7: Fatigue-crack growth rate for the as-quenched steel tempered at $600{ }^{\circ} \mathrm{C}$ with $R=0.1,0.25,0.5$
$\Delta K_{\text {th }}$. According to equation (2), the $\Delta K_{\text {th }}$ of the specimens tempered at $600{ }^{\circ} \mathrm{C}$ with $R=0.1,0.25$ and 0.5 were $11.65 \mathrm{MPa} \mathrm{m}^{1 / 2}, 10.49 \mathrm{MPa} \mathrm{m}{ }^{1 / 2}, 4.19 \mathrm{MPa} \mathrm{m}^{1 / 2}$, respectively, which are shown in Table 3.

Table 3: The $\Delta K_{\text {th }}$ under different stress ratios

\begin{tabular}{|c|c|c|c|}
\hline$R$ & $C_{1}$ & $n_{1}$ & $\Delta K_{\mathrm{th}}\left(\mathrm{MPa} \cdot \mathrm{m}^{1 / 2}\right)$ \\
\hline 0.1 & $1.17 \mathrm{E}-17$ & 9.31 & 11.65 \\
\hline 0.25 & $1.82 \mathrm{E}-19$ & 11.5 & 10.49 \\
\hline 0.5 & $2.21 \mathrm{E}-9$ & 2.65 & 4.19 \\
\hline
\end{tabular}

Fracture-surface morphologies of the FCG at the stage of stable expanding region for the steel tempered at $600{ }^{\circ} \mathrm{C}$ are presented in Figure 8, which indicated that the fractures were mainly composed of tearing ridges and secondary cracks. The arrows denoted the FCG direction. Figure $\mathbf{8 b}, \mathbf{8 d}$ and $\mathbf{8 f}$ are high magnification images of the circle line areas of Figure 8a, 8c and 8e, respectively. The high-magnification images show that the fatigue striations were perpendicular to the localized propagation direction of the fatigue crack. Meanwhile, the continuous distribution of fatigue striations were interrupted by some secondary cracks. The cracks may cause the acceleration of fatigue-crack growth rates during the process of coalescing with the main crack. ${ }^{30,31}$ It is noteworthy that some nanoparticles (marked by the white arrows) were presented near the secondary cracks. As a brittle phase, the spherical precipitates promoted the cracking of the matrix under cyclic loading during the fatigue-crack growth. The stress ratio had a significant effect on the slip behavior and fracture mode around the crack tip. Compared with the low multiple fatigue fractures, the size of the tearing edge increased with the $R$ ratios, the secondary crack density decreased with $R$ ratios. Figure $\mathbf{8 b}, \mathbf{8 d}$ and $\mathbf{8 f}$ illustrate that the striation separation was decreased with the $R$ ratios. This was consistent with the values reported previously for slip behaviour around the crack tip ${ }^{32,33}$.

\section{CONCLUSIONS}

In the present study, the microstructure, mechanical properties and fatigue crack growth of the heavy-forging steel $23 \mathrm{CrNiMoV}$ with quenching and tempering were investigated. The main conclusions can be summarized as follows:

- The microstructures of the quenched $23 \mathrm{CrNiMoV}$ steel tempered at $550-650{ }^{\circ} \mathrm{C}$ were tempered martensite. During the process of tempering, the $\mathrm{M}_{7} \mathrm{C}_{3}$-type acicular carbides precipitated mainly in the martensite lath, the $\mathrm{M}_{23} \mathrm{C}_{6}$-type spheroidal carbides precipitated mainly at the inter-plate boundaries and the prior austenite grain boundaries, and some spherical precipitates change into acicular precipitates with the increase of the tempering temperature. 

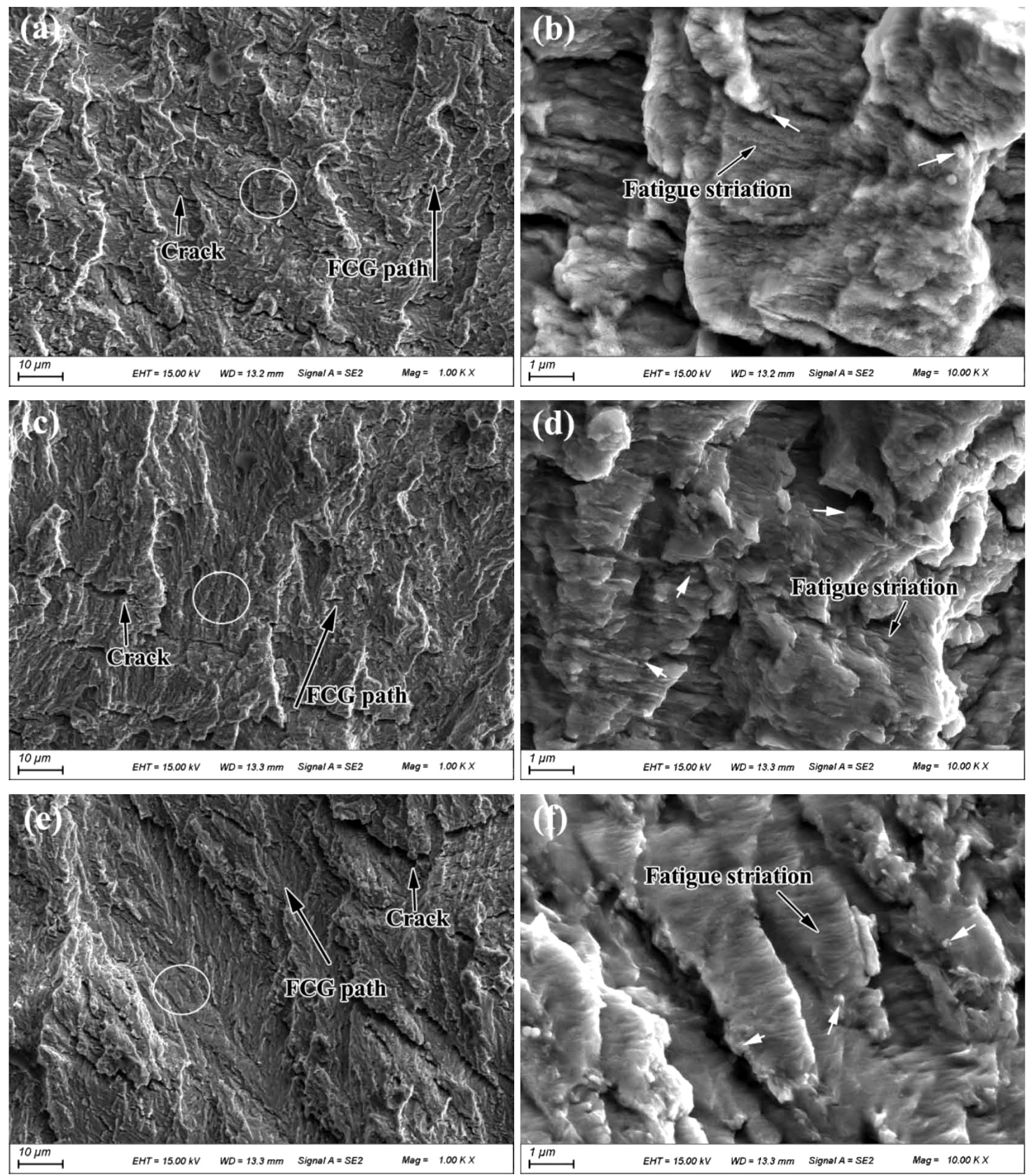

Figure 8: SEM micrograph of fatigue-fracture surfaces at the stable expanding region with the $\Delta K$ of $21.0-21.5 \mathrm{MPa} \mathrm{m}^{1 / 2}$ for the as-quenched steel tempered at $600{ }^{\circ} \mathrm{C}$ with different $R$, a,b) $\left.0.1, \mathrm{c}, \mathrm{d}\right) 0.25$, e,f) 0.5

- The high density of the dislocation in the tempered martensite region and the $\mathrm{M}_{7} \mathrm{C}_{3}$-type acicular carbides in the martensite lath significantly enhanced the strength and toughness of the $23 \mathrm{CrNiMoV}$ steel. The UTS, YS, elongation and impact energy of the steel tempering at $600{ }^{\circ} \mathrm{C}$ were $1155 \mathrm{MPa}, 1091 \mathrm{MPa}$, $15.4 \%$ and $102.9 \mathrm{~J}$, respectively.

- The FCG threshold $\left(\Delta K_{\mathrm{th}}\right)$ of the $23 \mathrm{CrNiMoV}$ steel tempered at $600{ }^{\circ} \mathrm{C}$ with stress ratio $R=0.1,0.25$ and 0.5 were $11.65 \mathrm{MPa} \mathrm{m} \mathrm{m}^{1 / 2}, 10.49 \mathrm{MPa} \mathrm{m} \mathrm{m}^{1 / 2}$, 4.19 $\mathrm{MPa} \mathrm{m}^{1 / 2}$, respectively. The fractures were mainly composed of tearing ridges and secondary cracks. The secondary cracks were easily produced around the spherical carbides, but coalesced with the main crack during the FCG.

\section{Acknowledgment}

The authors kindly acknowledge the joint support by the National Nature Science Foundation of China (No. 51775259), the Opening Project of Jiangsu Key Laboratory of Advanced Structural Materials and Application Technology (No. ASMA201704), Science Foundations of Nanjing Institute of Technology (No. QKJ201702). 


\section{REFERENCES}

${ }^{1}$ N. Harada, M. Takuma, M. Tsujikawa, K. Higashi, Effects of V addition on Improvement of Heat Shock Resistance and Wear Resistance of Ni-Cr-Mo Cast Steel Brake Disc, Wear, 302 (2013), 1444-1452, doi:10.1016/j.wear.2013.01.029

${ }^{2}$ M. Luke, I. Varfolomeev, K. Lütkepohl, A. Esderts, Fatigue Crack Growth in Railway Axles: Assessment Concept and Validation Tests, Eng. Fract. Mech., 78 (2011), 714-730, doi:10.1016/j.engfracmech. 2010.11.024

${ }^{3}$ L. Luo, Y. Huang, S. Weng, F. Z. Xuan, Mechanism-Related Modelling of Pit Evaluation in the Crnimov Steel in Simulated Environment of Low Pressure Nuclear Steam Turbine, Mater. Des., 105 (2016), 240-250, doi:10.1016/j.matdes.2016.05.058

${ }^{4}$ J. Zhe, J. Shen, P. Zhao, Short-term Creep of 91 Heat-Resistant Steels at Low Stresses and an Instantaneous-Stress-Change Testing, Mater. Tehnol., 51 (2017), 843-847, doi:10.17222/mit.2016.305

${ }^{5}$ C. Y. Chen, H. W. Yen, F. H. Kao, W. C. Li, C. Y. Huang, J. R. Yang, S. H. Wang, Precipitation Hardening of High-Strength Low-Alloy Steels by Nanometer-Sized Carbides, Mater. Sci. Eng., A, 499 (2009), 162-166, doi:10.1016/j.msea.2007.11.110

${ }^{6}$ V. A. Dub, A. Rodin, B. Bokstein, S. Belikov, P. Kozlov, I. Schepkin, V. S. Dub, Modeling of the Carbide Growth Kinetics in the Low Alloyed Steels, Mater. Lett., 215 (2018), 134-136, doi:10.1016/ j.matlet.2017.12.089

${ }^{7}$ J. Cao, Q. Yong, Q. Liu, X. Sun, Precipitation of MC phase and precipitation strengthening in hot rolled Nb-Mo and Nb-Ti steels, J. Mater. Sci., 42 (2007), 10080-10084, doi:10.1007/s10853-007-2000-4

${ }^{8}$ P. K. Patra, S. Sam, M. Singhai, S. S. Hazra, G. J. Ram, S. R. Bakshi, Effect of Coiling Temperature on the Microstructure and Mechanical Properties of Hot-Rolled Ti-Nb Microalloyed Ultra High Strength Steel, Trans. Indian Inst. Met., 70 (2017), 1773-1781, doi:10.1007/ s12666-016-0975-8

${ }^{9}$ M. C. Zhao, K. Yang, Y. Shan, The Effects of Thermo-Mechanical Control Process on Microstructures and Mechanical Properties of a Commercial Pipeline Steel, Mater. Sci. Eng., A, 335 (2002), 14-20, doi:10.1016/S0921-5093(01)01904-9

${ }^{10}$ N. Kamikawa, K. Sato, G. Miyamoto, M. Murayama, N. Sekido, K. Tsuzaki, T. Furuhara, Stress-Strain Behavior of Ferrite and Bainite with Nano-Precipitation in Low Carbon Steels, Acta Mater., 83 (2015), 383-396, doi:10.1016/j.actamat.2014.10.010

${ }^{11}$ G. Han, Z. J. Xie, L. Xiong, C. J. Shang, R. D. K. Misra, Evolution of Nano-Size Precipitation and Mechanical Properties in a High Strength-Ductility Low Alloy Steel Through Intercritical Treatment, Mater. Sci. Eng., A, 705 (2017), 89-97, doi:10.1016/j.msea. 2017.08.061

${ }^{12}$ G. R. Ebrahimi, A. Momeni, S. Kazemi, H. Alinejad, Flow Curves, Dynamic Recrystallization and Precipitation in a Medium Carbon Low Alloy Steel, Vacuum, 142 (2017), 135-145, doi:10.1016/ j.vacuum.2017.05.010

${ }^{13}$ J. Wang, P. D. Hodgson, I. Bikmukhametov, M. K. Miller, I. Timokhina, Effects of Hot-Deformation on Grain Boundary Precipitation and Segregation in Ti-Mo Microalloyed Steels, Mater. Des., 141 (2018), 48-56, doi:10.1016/j.matdes.2017.12.023

${ }^{14}$ S. G. Park, K. H. Lee, K. D. Min, M. C. Kim, B. S. Lee, Characterization of Phase Fractions and Misorientations on Tempered Bainitic / Martensitic Ni-Cr-Mo Low Alloy RPV Steel with Various Ni Nontent, Met. Mater. Int., 19 (2013), 49-54, doi:10.1007/ s12540-013-1009-2

${ }^{15}$ F. Hu, K. Wu, T. Hou, A. A. Shirzadi, Effect of Tempering Temperature on the Microstructure and Hardness of a Super-Bainitic Steel Containing Co and Al, ISIJ Int., 54 (2014), 926-931, doi:10.2355/isijinternational.54.926

${ }^{16}$ M. Y. Chen, M. Gouné, M. Verdier, Y. Bréchet, J. R. Yang, Interphase Precipitation in Vanadium-Alloyed Steels: Strengthening Contribution and Morphological Variability with Austenite to Ferrite Transformation, Acta Mater., 64 (2014), 78-92, doi:10.1016/ j.actamat.2013.11.025
${ }^{17}$ Z. Li, N. Xiao, D. Li, J. Zhang, Y. Luo, R. Zhang, Effect of Microstructure Evolution on Strength and Impact Toughness of G18CrMo2-6 Heat-Resistant Steel During Tempering, Mater. Sci. Eng., A, 604 (2014), 103-110, doi:10.1016/j.msea.2014.03.013

${ }^{18}$ J. Glownia, B. Kalandyk, Effect of Precipitation Strengthening in Low Alloyed Mn-Ni Cast Steels, J. Mater. Process. Technol., 207 (2008), 147-153, doi:10.1016/j.jmatprotec.2007.12.097

${ }^{19}$ W. Hui, Y. Zhang, X. Zhao, C. Zhou, K. Wang, W. Sun, H. Dong, Very High Cycle Fatigue Properties of Cr-Mo Low Alloy Steel Containing V-rich MC Type Carbides, Mater. Sci. Eng., A, 651 (2016), 311-320, doi:10.1016/j.msea.2015.10.124

${ }^{20}$ C. Ye, S. Suslov, B. J. Kim, E. A. Stach, G. J. Cheng, Fatigue Performance Improvement in AISI 4140 Steel by Dynamic Strain Aging and Dynamic Precipitation during Warm Laser Shock Peening, Acta Mater., 59 (2011), 1014-1025, doi:10.1016/j.actamat.2010.10.032

${ }^{21}$ K. Wen, B. Xiong, Y. Zhang, Z. Li, X. Li, S. Huang, L. Yan, H. Yan, H. Liu, Over-Aging Influenced Matrix Precipitate Characteristics Improve Fatigue Crack Propagation in a High Zn-Containing Al-Zn-Mg-Cu Alloy, Mater. Sci. Eng., A, 716 (2018), 42-54, doi:10.1016/j.msea.2018.01.040

${ }^{22}$ D. Huang, X. Yan, P. Li, X. Qin, X. Zhang, M. Qi, Z. Liu, Modeling of temperature influence on the fatigue crack growth behavior of superalloys, Int. J. Fatigue, 110 (2018), 22-30, doi:10.1016/ j.ijfatigue.2017.12.020

${ }^{23}$ W. S. Lee, T. T. Su, Mechanical Properties and Microstructural Features of AISI 4340 High-Strength Alloy Steel Under Quenched and Tempered Conditions, J. Mater. Process. Technol., 87 (1999), 198-206, doi:10.1016/s0924-0136(98)00351-3

${ }^{24}$ I. Fedorova, A. Kostka, E. Tkachev, A. Belyakov, and R. Kaibyshev, Tempering Behavior of a Low Nitrogen Boron-Added 9\% Cr Steel, Mater. Sci. Eng., A, 662 (2016), 443-455, doi:10.1016/j.msea.2016. 03.092

${ }^{25}$ C. Liu, Y. Liu, D. Zhang, B. Ning, Z. Yan, Effect of M3C on the Precipitation Behavior of M23C6 Phase During Early Stage of Tempering in T91 Ferritic Steel, Steel Res. Int., 82 (2011), 1362-1367, doi:10.1002/srin.201100153

${ }^{26}$ A. Rabiei, R. Derakhshandeh-Haghighi, Studying the Effect of PWHT on Microstructural Evolution and Mechanical Properties of Welded A517 Quenched and Tempered Steel, J. Mater. Eng. Perform., 26 (2017), 4567-4577, doi:10.1007/s11665-017-2868-3

${ }^{27}$ K. H. Lee, S. G. Park, M. C. Kim, B. S. Lee, Cleavage Fracture Toughness of Tempered Martensitic Ni-Cr-Mo Low Alloy Steel with Different Martensite Fraction, Mater. Sci. Eng., A, 534 (2012), 75-82, doi:10.1016/j.msea.2011.11.043

${ }^{28}$ J. Li, C. Zhang, Y. Liu, Influence of Carbides on the High-Temperature Tempered Martensite Embrittlement of Martensitic Heat-Resistant Steels, Mater. Sci. Eng., A, 670 (2016), 256-263, doi:10.1016/j.msea.2016.06.025

${ }^{29}$ M. L. Zhu, F. Z. Xuan, S. T. Tu, Effect of Load Ratio on Fatigue Crack Growth in the Near-Threshold Regime: A Literature Review, and a Combined Crack Closure and Driving Force Approach, Eng. Fract. Mech., 141 (2015), 57-77, doi:10.1016/j.engfracmech.2015. 05.005

${ }^{30}$ L. Lin, Z. Liu, X. Han, W. Liu, Effect of Overaging on Fatigue Crack Propagation and Stress Corrosion Cracking Behaviors of an Al-Zn-Mg-Cu Alloy Thick Plate, J. Mater. Eng. Perform., 27 (2018), 3824-3830, doi:10.1007/s11665-018-3518-0

${ }^{31}$ Z. Liu, X. Guo, H. Cui, F. Li, F. Lu, Role of Misorientation in Fatigue Crack Growth Behavior for NG-TIG Welded Joint of Ni-Based Alloy, Mater. Sci. Eng., A, 710 (2018), 151-163, doi:10.1016/j.msea.2017.10.090

${ }^{32}$ Y. N. Du, M. L. Zhu, X. Liu, F. Z. Xuan, Effect of Long-Term Aging on Near-Threshold Fatigue Crack Growth of Ni-Cr-Mo-V Steel Welds, J. Mater. Process. Technol., 226 (2015), 228-237, doi:10.1016/j.jmatprotec.2015.07.023

${ }^{33}$ D. Jeong, W. Seo, H. Sung, S. Kim, Near-Threshold Fatigue Crack Propagation Behavior of Austenitic High-Mn Steels, Mater. Charact., 121 (2016), 103-111, doi:10.1016/j.matchar.2016.09.035 